\title{
Themeda helferi (Panicoideae: Poaceae): A new record for India
}

\author{
Anil Kumar, M. ${ }^{1}$, Sreenath, A. ${ }^{1}$, Anjaneyulu, P. ${ }^{1}$, Saravanan, S. ${ }^{2}$ and B. Ravi Prasad Rao ${ }^{1 *}$ \\ 'Biodiversity Conservation Division, Department of Botany, Sri Krishnadevaraya University, \\ Ananthapur, Andhra Pradesh - 515 003, India. \\ ${ }^{2}$ Conservator of Forests \& Field Director, APFD-PTC, Srisailam, Andhra Pradesh, India. \\ E-mail: biodiversityravi@gmail.com
}

\begin{abstract}
Themeda helferi Hack. (Panicoideae: Poaceae) collected from the forests of Prakasam and Vishakapatnam districts of Andhra Pradesh, India, is being reported as a new record to India. A full description, notes, illustration, photographs and a distribution map along with comparative analysis with allied species, T. quadrivalvis (L.) Kuntze are provided.
\end{abstract}

Keywords: Andhra Pradesh, India, new record, Poaceae, Panicoideae, Themeda helferi, Vishakapatnam

\section{Introduction}

The genus Themeda Forssk. Comprising c. 29 species is distributed in Africa, temperate and tropical Asia, Australia, Pacific, North and South America (Clayton et al., 2006; Veldkamp, 2016). The genus is represented by 20 species (Bor, 1960, Karthikeyan et al., 1989, Kabeer \& Nair, 2009, Chorghe et al., 2016) in India. Of which, six are endemic, viz., Themeda mooneyii Bor (Andhra Pradesh and Oidisha), T. huttonensis Bor (Assam), T. odishae Chorghe et al. (Odisha), T. pseudotremula Potdar et al. (Maharashtra), T. sabarimalayana Sreek. \& V.J. Nair (Kerala \& Tamil Nadu) and T. saxicola Bor (Odisha); and two species, Themeda triandra Forssk. and T. quadrivalivis (L.) Kuntze are found throughout India (Singh et al., 2015; Chorghe et al., 2016).

As part of our floristic investigations in Andhra Pradesh state, the authors collected curious Themeda specimens in Thummalabayalu forest of Prakasam district; on the way to Janamguda near Araku and P. K. Gudem in Vishakapatnam district. After critical study, these specimens were identified as Themeda helferi Hack.

Themeda helferi was erected by Eduard Hackel (1889) based on two specimens collected by J.W. Helfer (Helfer 6809) now deposited in Kew (K 000245965, K 000245966) and cited its distribution in Tenasserim and Andaman Islands. Bor (1960) cited its distribution in Andaman Islands, which is followed by subsequent authors (Karthikeyan et al., 1989; Moulik, 1997; Pandey \& Diwakar, 2008; Murugan et al., 2016). It may be noted that Helfer's collections from Tenasserim (Myanmar) are mixed up with his collections from Andamans (India) as viewed by Thothathri (1977) and Mathew and Abraham (2001). Due to accidental death of J. W. Helfer, the collections were mixed up and these specimens were ascribed to either Tenasserim or Andamans in subsequent works. Since Themeda helferi has not been collected from Andaman Islands since 1860, it is presumed that the specimens were actually collected from Tenasserim, in Myanmar. Further, Chen and Phillips (2006) presented the species distribution only in Yunnan (China) and Tenasserim (Myanmar). Hence, our collections from different localities in Andhra Pradesh are the first from India and form a new record for the country.Since no lectotype is recognized, lectotypification of this species is warranted.

Themeda helferi Hack. in A.D.C. \& C.D.C., Monogr. Phan. 6: 665. 1889. Anthistiria ciliata var. helferi (Hack.) Hook.f., Fl. Brit. India 7 (21): 214. 1897. Themeda ciliata subsp. helferi (Hack.) A. Camus, Bull. Mus. Natl. Hist. Nat. 26: 424. 1920. Themeda quadrivalvis var. helferi (Hack.) Bor, Grass. Burm, Ceylon, India \& Pakistan: 252. 1960; Karthik. et al., Fl. Ind. Enum. Monocot. 268-269. 1989; Moulik, Grass. Bamb. India. Vol. 1. 233. 1997. Themeda acualis B.S. Sun \& S. Wang, J. Yunnan Univ. (Nat. Sci. Ed.) 21: 96. 1999.

Fig. 2, 3 


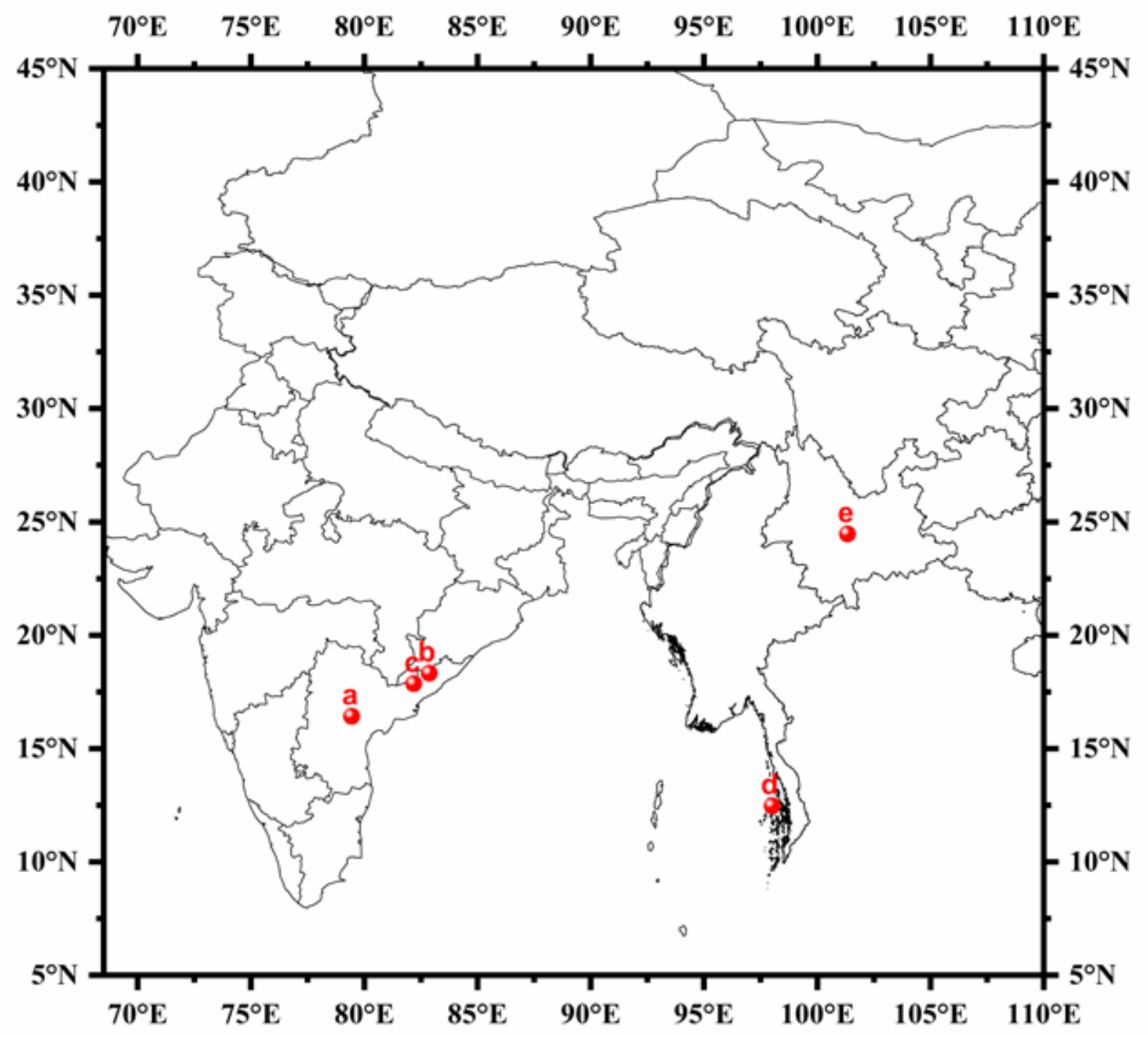

Fig. 1. Global distribution of Themeda helferi (a. Nallamalais; b \& c. Vishakapatnam; d. Myanmar; e. Yunnan)

Type: MYANMAR, Tenasserim, s.d. J.W. Helfer 6809 (K000245966).

Annuals. Culms solitary or caespitose, erect or geniculate-ascending, rooting from lowermost nodes, (15-)25-30 cm high. Leaf sheaths glabrous, laterally compressed, half to longer than their internodes; ligule membranous, truncate, ciliolate on upper margins, (1-)2-3 $\mathrm{mm}$ long; blades glabrous, $0.3-0.6 \times 15-20 \mathrm{~cm}$, acute to acuminate at apex, a few tubercle-based hair on lower margins. Inflorescence paniculate, composed of fascicled racemes, each raceme compact, subtended by a spathe. Principal spathe lanceolate, caudate acuminate at apex, margins membranous-hyaline, with few tuberculate hairs on margins in the middle, 2-3 $\times 0.2-0.3 \mathrm{~cm}$ long; secondary spatheoles similar to principal, but smaller in size, tubercles absent or very less on margins, $1.5-1.8 \times 0.15-0.18 \mathrm{~cm}$ long.
Spikelets seven in total; of which basal involucral spikelets four, sessile, sterile or male; companion sterile spikelets two, pedicelled, sterile; fertile spikelet one, sessile, bisexual. Involucral spikelets: Glumes 2, sub equal to equal in length, lower glume 4-4.5 mm long, glabrous, with few tuberculate ciliate hairs in upper half, upper glume glabrous. Lemmas hyaline. Paleas minute or absent. Stamens 3 , anthers 1.7-2 mm long. Companion pedicelled sterile spikelets: reduced to two empty sub equal glumes, 4-4.5(-6) mm long. Fertile spikelet: Lower glumes oblong, coriaceous, terete or rounded on dorsal side, 4-5 $\mathrm{mm}$ long, densely hispidulous to hispid on the dorsal midline; upper glumes as long as lower glumes, membranous to thinly coriaceous, flat. Lower lemma hyaline; upper lemma reduced to base of awn; principal lemma awn apical, geniculate, column twisted, 3-4 mm long, densely ciliate with stiff hairs. Palea minute 


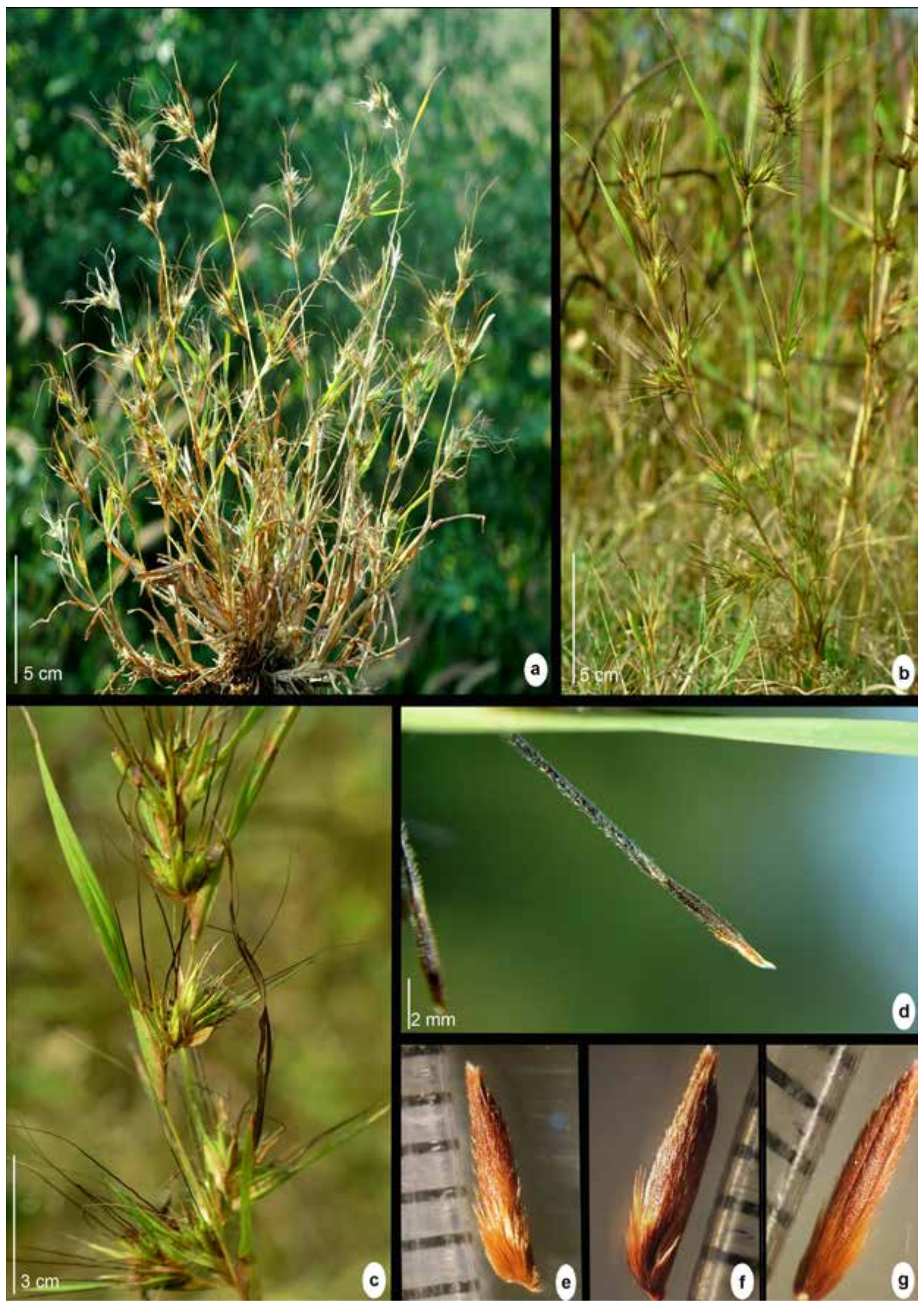

Fig. 2. Themeda helferi Hack. a. \& b. Habit; c. Close-up of racemes; d. Lemma; e-g. Different views of fertile spikelets (Photos by B.R.P. Rao \& M. Anil Kumar). 


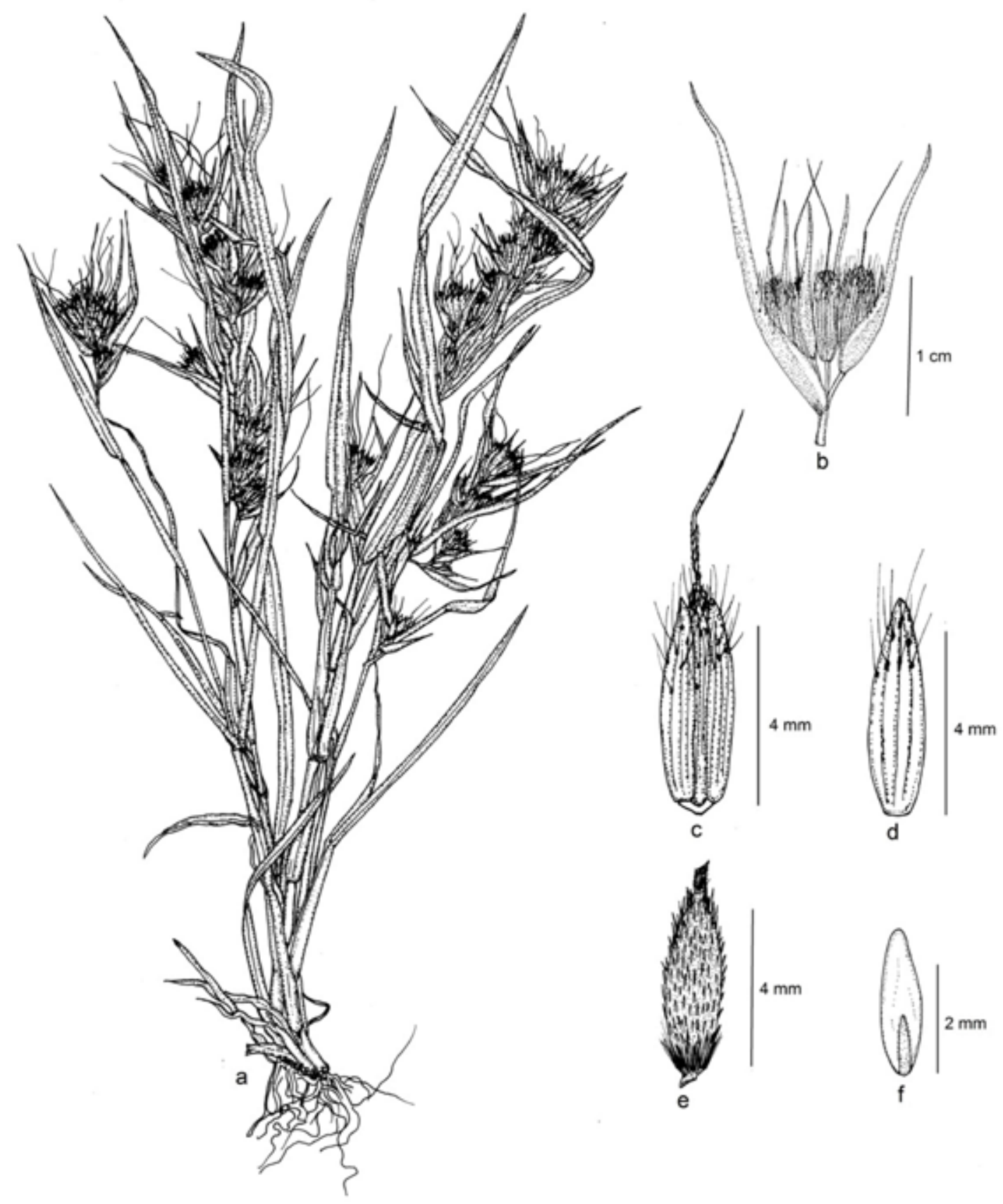

Fig. 3. Themeda helferi Hack. a. Habit; b. Fascicled racemes cluster; c. Cluster of spikelets in individual raceme; d. Lower glumes of involucral spikelet; e. Sessile fertile spikelet; $\mathbf{f}$. Caryopsis (Drawn by M. Anil Kumar).

or absent. Stamens 3. Stigma plumose. Caryopsis oblong, c. $3 \mathrm{~mm}$ long.

Notes: Themeda helferi Hack. is closely similar to T. quadrivalvis (L.) Kuntze, but can be easily differentiated from the latter by its dwarf habit, inflorescences usually arising from basal leaf sheaths with sparse tuberculate hairs on upper half of involucral glumes and hispid or hispidulous on dorsal middle line of lower glumes of sessile spikelets.
Flowering $\mathcal{E}$ fruiting: October - March.

Distribution: China, Yunnan (Longling, Zhenkang); Myanmar (Tenasserim), India (Andhra Pradesh).

Habitat \& ecology: Found along way sides in the moist deciduous forests and forest margins.

Specimens examined: INDIA, Andhra Pradesh, Vishakapatnam district, way to Janamguda, near Araku, 29.11.2016, B.R.P.Rao, M. Anil Kumar \& P. Anjaneyulu 52576 (SKU); near P. K. Gudem, 
Table. 1. Comparison of morphological characters between Themeda quadrivalvis and T. helferi

\begin{tabular}{lll}
\hline Character & Themeda quadrivalvis & T. helferi \\
\hline Culms & $\begin{array}{l}\text { Moderate to robust, } 30-200 \mathrm{~cm} \\
\text { high }\end{array}$ & $\begin{array}{l}\text { Short, 10-30 cm high } \\
\text { Inflorescence }\end{array}$ \\
$\begin{array}{l}\text { Racemes usually arising from the } \\
\text { upper leaf sheaths }\end{array}$ & $\begin{array}{l}\text { Racemes usually arising from the basal leaf } \\
\text { sheaths; and hence culms and inflorescence } \\
\text { appear equal in height. }\end{array}$ \\
Fertile spikelets & Hispidulous or hispid at tip only & $\begin{array}{l}\text { Hispidulous or hispid throughout the dorsal } \\
\text { surface }\end{array}$ \\
\hline
\end{tabular}

15.12.2017, B. R. P. Rao \& M. Anil Kumar 52997 (SKU). Prakasam district, Nallamalias, near Thummalabayalu base camp, 27.12.2016, B.R.P. Rao, M. Anil Kumar, A. Sreenath \& P. Anjaneyulu 53069 (SKU).

\section{Acknowledgements}

One of us (BRPR) is grateful to University Grants Commission (UGC) for BSR-OTG Project (No. F. 19-151/2015 (BSR) and MAK to National Remote Sensing Agency (NRSC/FEG/VCP - 2015) for the Junior Research Fellowship. Authors also thank to Andhra Pradesh Forest Department regarding permission to the field work.

\section{Literature Cited}

Bor, N.L. 1960. The Grasses of Burma, Ceylon, India and Pakistan (excluding Bambuseae). Pergamon Press, Oxford.

Champion, H.G. \& S.K. Seth 1968. A revised survey of the forest types of India. Govt. of India, New Delhi.

Chen, S.L. \& S.M. Phillips 2006. Themeda Forssk. e-flora of China, 22: 633-635. http://www.efloras.org/florataxon.aspx?flora_id=2\&taxon id $=132780$

Chorghe, A., Prasad, K., Prasanna, P.V. \& Y.V. Rao 2016. A new species of Themeda (Poaceae: Panicoideae) from the Eastern Ghats, India. Phytotaxa 245(2): 183-186.

Clayton, W.D., Vorontsova, M.S., Harman, K.T. \& H. Williamson (2006 onwards). Grass Base the online world grass flora. http://www.kew.org/ data/grass.db.html (Accessed: 01.03. 2017)

Hackel, E. 1889. Themeda helferi Hack. In: De Candolle, A.L.P.P \& De Candolle, A.C.P. (Eds.), Monographiae Phanerogamarum. Vol. 6 G. Masson, Paris. pp. 665.
Kabeer, K.A.A. \& V.J. Nair 2009. Flora of Tamil $\mathrm{Nadu}$ - Grasses. Botanical Survey of India. Kolkata.

Karthikeyan, S., Jain, S.K., Nayar, M.P. \& M. Sanjappa 1989. Florae Indicae Enumeratio Monocotyledonae. Botanical Survey of India, Calcutta.

Mathew, S. \& S. Abraham 2001. On Helfer's Collection of Piper ribesioidesWall., from the Bay Islands, India. J. Bombay Nat. Hist. Soc. 98(3): 491-92.

Moulik, S. 1997. Grasses and Bamboos of India. Vol. 1. Scientific Publishers, Jodhpur.

Murugan, C., Prabhu, S., Sathiyaseelan, R. \& R.P. Pandey 2016. A Checklist of Plant of Andaman and Nicobar Islands. (edited by Singh, P. \& Arisdason, W.) ENVIS Centre on Floral Diversity, Botanical Survey of India, Howrah. Published on the Internet: h t t p : / / www.bsienvis.nic.in/Database/Checklistof Andaman- Nicobar- Islands_24427.aspx (accessed on 02.06.2018).

Pandey, R.P. \& P.G. Diwakar 2008. An integrated check-list flora of Andaman and Nicobar Islands, India. J. Econ. Taxon. Bot. 32 (2): 403500.

Singh, P., Karthigeyan, K., Lakshminarasimhan, P. \& S.S. Dash 2015. Endemic Vascular Plants of India. Botanical Survey of India, Kolkata.

Thothathri, K. 1977. A review on the floristic studies in the Andaman and Nicobar Island up to 1970. Bull. Bot. Survey India 19: 127-131.

Veldkamp, J.F. 2016. A revision of Themeda (Gramineae) in Malesia with a new species from Laos. Blumea 61: 29-40.

Received: 01.02.2018

Revised and Accepted: 10.06.2018 